\title{
RECONSTRUCTING THE FEMALE SEX IN EMERGENT NOVELS
}

\author{
Muhammad Alkali \\ Ibrahim Badamasi Babangida University, Lapai, Nigeria \\ muhalkali@yahoo.com
}

\author{
Rosli Talif \\ Universiti Putra Malaysia, Malaysia \\ rt6272@yahoo.com
}

\begin{abstract}
The notions of, which are at once both anti-masculinity and anti-femininity are topmostaspects of Negotiation-feminism. This new feminism emphasizes the fact that we owe feminism the power and honesty in reconciling the sexes in every prejudice against woman. The significant findings are that a very plausible answer, for example, to a previously unanswerable question has been found against domestic subjugation, and necessarily, such discourse as new novels by new writers on new woman is identifiable. The paper, therefore, argues for the need to step forward together between the sexes in the feminist aspects of exemplary Nigerian novels, demonstrating how the emergent feminist wake-up call repositions woman in improving the lives of housewives and, of course, their husbands. With fire and imaginative power, this wake-up call strengthens feminist civilization towards civility of reconciliation between the sexes.
\end{abstract}

\section{Keywords}

Gender, Nego-feminism, Nigerian novel, womanhood, postfeminism

\section{About the Authors}

Muhammad Alkali is a PhD holder in Cultural and Literary Studies. He is with the Department of English, Ibrahim Badamasi Babangida University, Lapai, Nigeria. He works mostly on sexuality and gender studies in third-world countries.

Rosli Talif is Associate Professor of English Studies at the Faculty of Modern Languages and Communication, Universiti Putra Malaysia (UPM), Malaysia. His main interests include issues in literature and gender, gender roles in literature and the media, gender concerns in children's literature, and language policy and planning in Malaysia. His publications interlink language and literature while re-examining existing paradigms that affect the way we conceptualize the roles, functions, and developments of language and literature in society. 


\section{PRELIMINARY STATEMENTS ON THE FEMINIST NEW ORDER}

A taxonomy of an emergent culture of 'assertion' in redeeming the feminist image is presented. The taxonomy categorizes emergent mechanics of image redemption according to: (a) new novels; (b) new writers; and (c) new woman. This taxonomy is readable through Nego-feminism, which, simply put, attempts to unite feminist strategies in winning the war against dehumanization of the female sex throughout the patriarchal world. Nego-feminism deals with ego in both sexes; it is therefore both anti-masculinity and anti-femininity. Thus, the taxonomy of new novels, new writers, and new woman should tremendously assist to give the world a new order for demanding welfare economics of the sexed body which has been treacherously fetishized for long. Efforts have been on to defetishize her, but the challenges remain intimidating.

In stressing feminism's intimidating challenges, Charlotte Brunsdon's “The Feminist in the Kitchen" charges that all feminist efforts (as championed by socialist-feminism, liberal-feminism, radical-feminism, Western feminism, Iranian feminism, French feminism, etc.) are only recycled, as there has not been meaningful headway that pulls the woman truly out of the doldrums (41-56). Earlier, Ginia Bellafante charges that "[f] eminism is dead! . . In the 7os', feminism produced a popular culture that was intellectually provocative. Today, it's a whole lot of stylish fluff ... Fashion spectacle, paparazzi jammed galas, mindless sex-talk, is this what the road map to greater female empowerment has become?" (56-60). As it is, these feminists that distance themselves from radical feminism will be pleased when they are dead. That will let them off from worrying about all these glamorous fashions.

Following Bellafante's exposition, the female body has always been front and center in discussions of twenty-first century radical feminism. This postfeminism does its utmost for body slimming, and focuses on how the female body is fitted for public view or glamour. To these postfeminists, age is an enemy that must be squarely addressed, and the surest way of doing this is through plastic surgery. Consequently, Diane Negra's What a Girl Wants? adequately discusses "postfeminist body perfection" (121) vis-à-vis the "hyper aesthetization of everyday life" (152). Negra mentions the rejuvenalization of the vagina as a tendentious example for achieving body fitting. To exemplify Negra's position, the filmic Sex and the City, an American television series launched in 1998 by HBO (Home Box Office 1998-2004) is aimed at cosmopolitanism, sexual freedom, independence, and female friendships through the example of four young New Yorker women. At the center for all the characters is their glamorous emergence; they practice fitness by doing yoga and training for marathons. The characters are seen at health resorts or beauty institutes. Samantha particularly is after rejuvenating her image and body; she is particularly self-absorbed and not afraid of Botox injections and 
chemical peelings to look more youthful. Peculiarly for Samantha, a man places her age at 40-41. But a voice says "Samantha has celebrated her 35 th birthday for as long as we can remember" ("The Freak Show"). It is precisely because of these drummed up issues that critics of fashion feminism feel that feminism can no longer exhibit difference and deference. To them, "[f] eminism is dead!" (Bellafante 56)

This paper sees the morphologies of fashion feminism, socialist feminism, liberal feminism, radical feminism, Western feminism, Iranian feminism, French feminism, Malaysian feminism, etc. as less effective in their attempts to express rightful sentiments that differentiate woman from a doormat. Indeed, Raven, Tasker and Negra, and McRobbie provide a secure basis to argue that all is not well with feminism still. These feminist literary critics observe less successful attempts in feminist efforts so far, arguing that feminism may have not yet produced concrete answers to the plight of the woman where achievements could tailor a live and let live' culture (i.e. Nego-feminism), where there would be harmony and sexual development in the world, not discord between the sexes. No one wants discord in the world (Tasker and Negra 108). At one point, when the historian Joan Wallach Scott, the author of Feminism's History, was approached on "where women's history should, or might, go from here," she found herself "running up against a wall." All, indeed, is still not well with feminism. This will be explained further.

Evidences of male-dominant/female-submissive dynamics still exist, sadly. The female world cannot afford to underestimate the most crucial factor in men's traditional disregard and contempt for women's modes of existence: the reality of male power. This is the particular reason why women aggressively insist on feminism. Postfeminist writings have been particularly encouraged to inscribe the experiences of women under patriarchal domination. A little scholarly search would reveal innumerable gripping dramas of domestic violence and domestic 'pornography of violence' (i.e. rape) because of men's built-in power, men wishing not to have their home decisions countered, etc. In both Abubakar Gimba's Sacred Apples and Stella Ify Osammor's Triumph of the Water Lily, bedroom politics play out meaningfully between husbands and wives to the extent of overheated challenges, but these were ably reconciled through Nego-feminist methodologies. Conversely, the world could have reasonably had 'hope' that, with the rejuvenation of feminism from the 1980s, women could have nearly brought to an end the institutional dynamics against womanhood. Women and thinking men have long been in a position to do just that, but oppositional feminist streaks might have disallowed it. Less effective techniques need to be assessed in order to rediscover womanhood. This is the observable trend in Nego-feminist new novel writing in Nigeria. We can look more closely at its persuasive power and materiality. 
It was in 2012 when the Nigerian Vanguard newspaper ran a horrifying report: "Man who burnt wife with hot iron opens up, as emotions pour in for burnt wife." The reporter, Evelyn Usman, revealed the reason. A 38-year-old husband, Henry Nnadi, not only burnt his wife, Mercy, on April 7, 2012 but also killed his one year old son, Ebuka, at the same time out of anger, as he doubted the paternity of the baby. His wife, he alleged, had been sleeping with his biological father. Mercy sustained third degree burns. Here is what the feminist world did.

Upon publication of the story, some concerned Nigerians and groups put in phone calls indicating interest in assisting Mercy with the medical bill and a possible transfer to a better hospital. Included in this group of sympathizers were the Zahara Women Foundation, CENTA for Organizational Development, Bimbo Odukoya Foundation, as well as individuals in and outside Nigeria. This, in our opinion, is curative feminism instead of preventive feminism. What is the point of simply providing assistance to Mercy when the world can actually step forward together to prevent feminist issues of this nature from occurring? With Negotiation-feminism (Nego-feminism), things do not heat up to a dangerous level between partners. Therefore, theories of féminité must not remain fixated within the curative frameworks they attempt to use to dislodge patriarchal order; they must look to proactive feminism, which this study emphasizes. Doubtlessly, the feminist world has been offended but it must guard its responses, and, happily, emerging or new techniques are revealing themselves in new novels in Nigeria to checkmate male dominance.

This is perhaps why Fien Adriaens and Sofie van Bauwel posit at length that no matter what anyone feels, feminism shall survive (190). This postfeminist position is upstaged by this paper as we think there will always be the need for new efforts that will look to new possibilities. The seeming 'dead end' is therefore negotiable and, in fact, already being negotiated. In recent years, negotiation order research has emerged as a major focus of research interests (see, for example, Kolb and McGinn; Exner et al.; Loe; Tavris; Morawski; and de Berker). Amidst a growing tension between the sexes, there has equally been a growing recognition that negotiation between couples should help them tolerate one another more effectively. Thus, in spite of the fact that feminists have built and are still building up the fires of hate between the sexes, an emergent feminist wake-up call, Nego-feminism (i.e. Negotiation-feminism) promises a good present for a collective positive future more than any framework before it. And so it needs to be asked: how does it diffuse tension between couples and what can teachers and writers do to foster it in the classroom and in novel-writing for the wider advantages of the public? 


\section{THE CONCEPT OF NEGO-FEMINISM}

J.H. Flavell's popularly cited "thinking about thinking" (906-11) has always provided a suitable point of entry into the inspiration of many critics and authors who found themselves (in)directly dealing with, for example, Nego-feminism as recipe for development. They pour so much of themselves into the investigation of peace studies on the gendered tension between the sexes. They have read and heard about several peace initiatives between the sexes and have wanted to know how the tension can be diffused.

The critics and authors aim to clear the world's head of all sexual prejudices (but specifically between couples-our concentration) and learn about the beliefs, views, and philosophies on life that differ between the sexes; this effort is anchored on uncommon fate and uncommon bond where women will no longer be surviving at the margins. The paper urges all to ignore readings on inessential woman with its challenges of exclusion and unacceptable conclusions on woman and man alike, and try to learn as much as possible about this peace study on the excitement between the sexes. Nego-feminism exploits areas for lovers of peace. The world needs peace and dialogue and the first step is by understanding one another. Perhaps, in a not-so-distant time, we might reach a state of mutualism and symbiosis across the globe. The currency of mere sexual mockery and antagonism from either of the sexes, therefore, is not helpful. From its birth to date, Negofeminism enjoins the world to try to learn and understand its motifs as we try to understand the world around us.

In 1999, the originator of Nego-feminism, Obioma Nnaemeka, became a compelling feminist theorist with a fierce intellect in redefining the patriarchal world. To her, Nego-feminism is simply "the feminism of negotiation; no ego feminism" (360). It rediscovers masculinity and femininity and then challenges the masculinist and feminist ego by asking: are the present and future male and female still troubled? In this sense, Nego-feminism does not antagonize the opposite sex as it expands the boundaries of woman and man. It chooses to exploit issues of peace, peace study and resolution, negotiation, complementarity, give-and-take, collaboration. It urges the sexes to try to be oft-forgiving of their partner's mistakes. Nego-feminism has, therefore, eliminated so much of the aggressive rhetoric of incitement in literatures that give the impression that all men are (potential) rapists and take hurrying, rough, unkind, impatient approaches to dealing with their wives, or at the most, that sisterhood or solidarity among women is a doubtful possible source of solace or a vague anchor of hope because of its rascality in the eyes of men. 
Nego-feminism proposes that for the world to be taken to greater heights, both sexes need to join hands to combat the sexist world. Thus, the struggle against sexism is no longer the affair of women only; men stand side by side with their women to see to a new world of mutual symbiosis.

Nego-feminism is not unaware of attendant challenges. For example, it needs to be asked is reconciling the sexes not easier said than done? Would it not suffer the fate of its predecessors as mere recycling of the woman's agenda? In truth, Nego-feminism recognizes that the hardest kind of its activity is negotiation, for if the two parties are not willing to be reconciled, the sexes hardly stand a chance for negotiation. Particularly, Miller's comparative study, "The Negotiation Style," has called attention to stated and in-practice styles of negotiating peace between people. But there is hope, as scripturally, mankind has been reminded of the concept of brotherhood and sisterhood consequent upon the need to foster peace and reconciliation among human beings (The Qur'ān, 49.10 and 4.128). Interestingly, what the scriptures say compares to what new novels instigate on this brand of reconciliation. New novels are poised for a discourse along Nego-feminist lines.

\section{THE EMERGENCE OF NEW NOVELS IN NIGERIA}

While the space-claiming mission of the British author Griswold in 2000 picked about 500 books - through the large pockets of the National Science Foundation, the Woodrow Wilson International Center for Scholars, the National Endowment for the Humanities, the University of Chicago Humanities Institute, and the Center for Advanced Study in the Behavior Sciences "either directly or in terms of fellowship support" - which enabled her to assess the nature and potentials of readers, writers, and the Nigerian novel industry from 1970s to 1990 s (xii), the Nigerian Femi Abodunrin's similar effort in 2006 is a scholarly intervention using about 450 books, book chapters, and journal articles from 1991 to 2001. The two scholars have demonstrated vigorous arguments that African literature has a lot of intense intellectual activities in its literary practice. Both Griswold and Abodunrin are witnesses to Nigerian novels' contribution to colonial intrusion onto African soil and the attendant collateral damage thereafter. These eminent critics have stated that the novels derive their strengths from tribal sources (oral literature) alongside arbitrary colonial borders. Now these two old-fashioned areas provoked curiosity into new intense debates on women's ambivalence about motherhood, sex, and work in a way that was instantly controversial but profoundly influential. The new trend in novels has to do with women's amiability to the challenges of motherhood, sex, and work. 
New novels today are demonstrating competence in refusing to exploit the context of a historical past of colonial intrusion or even underscore the relevance of feminist oral literature. Particularly for this paper, what is now known as Negofeminism is now central to the dominant culture of feminist negotiation in new novels in Nigeria. In making women matter, Nego-feminism is meeting practical and strategic needs for a global sisterhood-at least, Robin Morgan hints towards the fact that "sisterhood is global" so that conduct unbecoming of both masculinist and arrant feminist angst is quickly resolved between the sexes.

Novels such as $26 a$ (published in 2005) by Diana Evans, Half of a Yellow Sun (2006) by Chimamanda Ngozi Adichie, The Icarus Girl (2005) by Helen Oyeyemi, Sky-High Flames (2005) by Unoma Azuah, Everything Good Will Come (2005) by Sefi Atta, House of Symbols (2001) by Adimora-Ezeigbo Ezeigbo, My Husband Wants to Marry Me Again (1996) by Grace Okafor, The Triumph of the Water Lily (1996) by Stella Ify Osammor, and Sacred Apples (1994) by Abubakar Gimba are only a few textual instances pointing to the increasing outspokenness and explicitness that are partly elemental to nego-feminist streaks among new novels in Nigeria. In the methodological design of this essay, Osammor's Triumph of the Water Lily (hereinafter Water Lily), and Gimba's Sacred Apples will serve as pioneer novels in the spirit of Nego-feminism. It is always good to start from the beginning so as to be able to investigate how a process has fared. Future endeavors might wish to turn their attention to how the process has fared for richer comparative results.

These novels do not brood on persistent inequalities where women live in subhuman conditions as pleases men. They do not brood in tragedies. For ages now, women have lived with the question, "Are servants ever sisters?" Several accounts of the damage of patriarchy are appalling, and many cannot understand the mindset of those who will not stop attacking womanhood so that the female sex remains exploited. The question on everyone's mind, and one that has been voiced by many feminists, is how far patriarchy is truly going to go. Feminists have had to contend consistently with discrimination and have in turn devised perhaps excessive ways and means of resolving the face-off. The question is, how far can patriarchy go until women fall? Happily, feminists now do not need to fall. Negofeminism comes intelligently to the rescue, and interestingly, it is protective of both sexes. Writers of Nego-feminism under study here have demonstrated considerable symbiotic status recognition to the sexes. Who then are these writers? 


\section{THE NEW WRITERS OF NEW NOVELS IN NIGERIA}

Maik Nwosu's “The Mapping of a Generation" has, foundationally paved the way for the understanding of anyone interested in the creation of generational writings in Nigeria. He has provided the schema for approaching the arrival of writers of different generations in Nigeria. The first generation writers had always engaged issues of "the empire writes back," observing the misplaced preoccupation of Western writers with "primitive Africa." Chinua Achebe's Things Fall Apart, for example, is often the first African novel encountered to repudiate this wrongful reading of a primitive allegation. For most genuine readers, the book is known for praising the African culture in the early 2oth century, while revealing a criminal intrusion of the British colonial order. Achebe makes it clear that his objective in writing is to give any reader of Africa a realistic depiction of their pre-colonial past, free of the distortions and stereotypes imposed in accounts of, for example, Heart of Darkness by Joseph Conrad and Mister Johnson by Joyce Carry. In espousing this fundamental issue, African first generation writers of fiction often deliberately forget aspects of feminism, arguing that "fundamental theme must first be disposed of" (Achebe 8). Thus, Achebe's women characters, like all women in the storylines of first generation, are consequentially inessential.

Happily, in second generation writings, "the African female character, the essential female has just emerged" (Positivism 3). The Nigerian women writers and scholars decided "to conceptualize, contextualize, and theorize African feminisms" with "an assertive woman." The women thinkers of this generation include, but are not restricted to, Ada Azodo, Aisha Imam, Akachi Ezeigbo, Amina Mama, Bolanle Awe, Buchi Emecheta, Calixthe Beyala, Catherine Acholonu, Chikwenye Okonjo Ogunyemi, Chioma Opara, Filomina Chioma Steady, Florence Abena Dolphyne, Gloria Chukukere, Helen Chukwuma, Ifi Amadiume, Juliana Nfah-Abbenyi, Mary E. Modupe Kolawole, Marie Umeh, Molara Ogundipe-Leslie, Nnaemeka Obioma, Olabisi Aina, Omofolabi Ajayi-Soyinka, Oyeronke Oyewumi, Simi Afonja, Zaynab Alkali, and Zulu Sofola. These writers and scholars presented a new African woman who had evolved from "the slave girl prototype to the career mother and single fulfilled woman" (3). The writers and scholars took a step further. A third generation was born from this second.

In 2008, Alkali's “Thematic Shiftings in the African Novel: Another Assessment' labored to strengthen the arrival of the third phase. In pursuit of the goal of locating these writings and writers, the local cultural influences circulating around them are part of Africa's matrix of overlapping 'scapes. Thus, there is an overlap of thematic concerns between the second and third generation writings, but the third generation has succeeded in driving feminist culture and agendas in significant new 
ways. Analyses of these generations by Nadaswaran (19), Akpuda (151), and Akosu (36-7) are also commendable efforts and their findings remain overwhelming.

The third generation writers are young in age compared to those of the first and second generations. Almost all of the writers have their dates of birth in the 1960s, and thus all topical issues of Africa such as colonialism, independence, and the civil war are "known" only by their echoes through the subsequent decades. Enitan, the heroine of Everything Good, clearly states, "I was born in the year of my country's independence, and saw how it raged against itself" (Atta 330). Kambili of Purple Hibiscus is also born in the decade following Independence and is a teenage witness to events in the 1980s. Speaking the same language, revelations of the twins in $26 a$ take them to Lagos in the 1980s when they are children. Yellow Sun is set before and during the Biafran War; Ofunne of Sky-High Flames, born in 1937, is a schoolgirl and young wife in the pre-Independence decade of the '50s; the story of Eaglewoman in House of Symbols and her family is set in the 1940s and 1950s. The only exception is Icarus Girl which is set in an unspecified time, a generalized computer-age in the late twentieth century. All of these novels are, then, predominantly historical, selfconsciously recreating specific moments in Nigeria's recent or pre-Independence past. One reviewer goes so far as to say of Ngozi Chimamanda Adichie: "I look with awe and envy at this young woman from Africa who is recording the history of her country. .." (White qtd. in Half of a Yellow Sun). More specifically, these third generation writings have taken over the commanding heights of feminist culture through the formidable power of assertion versus negotiation themes through their new woman agenda. Let us look at this new woman more closely.

\section{THE EMERGENCE OF NEW WOMAN IN THE NIGERIAN NOVELS}

Modern critical thinking and practice of feminism has been thriving in and outside Africa. It has been exciting because it has been daring to venture into fiction with such diverse and sometimes surprising representations and explorations of women, of their relationships with each other and with men, that its outgrowth has particularly created a new direction for fiction in Nigeria in recent years; it has come to be called Nego-feminism in the third generation writings. (For third generation writings, see Nadaswaran 19, Akpuda 151, and Akosu 36-7.) Negofeminist writings reveal extraordinarily self-aware thinkers and writers, possessing the ability to criticize patriarchy without confrontation or outright arrogance. It is patronizing and not polemicizing. For them, it appears no great effort to balance Nego-feminist intentions with broad feminist critique; it reconciles warring parties. How did it shoot up after so much has been done? We will let this concern occupy this section. 
With Nego-feminism, a new woman emerges. Thus, in the new novels of Negofeminism, the new woman does not give in to "reclaiming wholeness," or being "strong-willed" or "self-assertive." Nadaswaran dissects the distinct paternalistic young girl-child/woman protagonist who is usually a "strong womanist," "reclaiming wholeness," "authority," "strong-willed" and "self-assertive" (19-20). This "assertive" protagonist is anti-nego-feminist, and is not likely to take womanhood to the desired level in the twenty-first century. And it is important to ask: how may this new woman be more clearly identified in the new novels? Let us look closely at the characteristics.

Susan Arndt offers a pathway to discuss characteristics of the new woman in new novels of third generation writings. Firstly, a multitude of new novels exists in Nigeria (see Alkali et al. 136) as the Nigerian nation seems to have lost count of the incredibly large number of these new novels (Alkali et al. 137). The representative new works in this section include, but are not restricted to, Gimba's Sacred Apples and Osammor's Water Lily.

Disclosures show that Arndt's classification of African-feminist literatures into "reformist," "transformative," and "radical" heralds the clearly non-radical characteristics that are to be found in Nego-feminist novels, because both "reformist" and "transformative" characteristics do not question one sex's right to dominate and control. Though these two reject the notion that "aware" women are deviant, they yet recognize the fact that radical-feminism-commonly shared by women-is intelligible only to women and men who work with, live with, and articulate critical judgement over women and men, and have no faith whatsoever in the system's fairness to both sexes. In this way, Nego-feminist novels align with a balanced assessment of feminist dramas. There are other characteristics.

Carole B. Davies and Anne A. Graves suggest a definition of African feminism that they did not know would, with time, morph into Nego-feminism that would reconstruct womanhood:

African feminism ... is not antagonistic to African men but challenges them to be aware of certain salient aspects of women's subjugation which differ from the generalized oppression of all African peoples ... [it] examines African societies for institutions which are of value to women and rejects those which work to their detriment and does not simply import Western women's agendas. [It] understands the interconnectedness of race, class, and sex oppression. $(8-10)$

Davies and Grave's suggestion for African feminism fits the Nego-feminist woman. She does not antagonize her man. She does not pronounce serious judgment on serious issues like, for example, the opposite sex who attempts to, or 
even does, bypass the justice system. This was particularly explored in the feminist drama of Chikwenye Okonjo Ogunyemi, African Wo/man Palava, where she deliberately plots a translation of the 1929 Igbo phrase "Ogu Umunwanyi," a volatile discourse for "Women's War" into "Women's Struggle," an intelligently softened word for war (see Ogunyemi 11). When "struggle" replaces "war," a new agenda, a new mentality is gracefully presented. Such discourses are worth exploiting in order to give the world better cohabitation between the sexes. Of great concern to this new woman agenda (Nego-feminism) then is the luring genderization of sexual power and institutional power, so that it will intelligently relinquish a confrontational poise and yet achieve its desired result. This hinges on the fact that a man and a woman literally do not take turns in exerting the power to kill, torture, maim, or humiliate the opposite sex - if they do, both parties would be demonstrating extremism and therefore, both would be 'wrong.'

Gentle behavior towards one's spouse is a causal part of participatory decisionmaking in Nego-feminism. A husband, for instance, should not hurt his wife's feelings or indulge in any theoretical turns against gender. Treating her tenderly engenders willingness to open up, and encourages the partners to opt to listen to each other. It engenders good interaction such as remembering to inquire about what disturbs her (like when the children do not obey her instructions in the house). Communication, compromise, and consideration are key to healthy matrimony. We would take examples from Gimba's Sacred Apples on how men hurt women's feelings and then ask: should women take turns against their men? Gimba became more forceful in discourses like this when a whole conference was organised in his honor, "National Conference on Life and Writings of Abubakar Gimba" in August 2015. It discussed his guiding wisdom and philosophy which had culminated in a series of his literary efforts, among which is his Sacred Apples. The dramatization of feminist conflict in Sacred Apples is not only innovative for its being a leading third generation novel on Nego-feminism but also useful, and sheds light on the rounds of feminist hostilities between principal actors. (see Unoma Azuah's "Reshaping Obliterated Faces" for the classification of third-generation Nigerian writers).

Sacred Apples works to convert the simplicity of female subjectivity into complexity. It takes issue with the heroine, Zahrah; as the novel opens, her grandmother, Zubaydah, is saddened by the hooting of an owl, a signal of impending danger to the expected granddaughter, Zahra. This is in accordance with the community's age-long mythopoeia. Gimba follows the myth to reveal the multiple jeopardies of Zahrah's divorce, the mob action by irate students of the Songhaian National University in partnership with the Songhaian Labour Solidarity, Zahrah's abduction, the burning of her husband's government car with her three children in it, and the supposed consequent death of the children, all of which relate to the tenets of marriage institution. Whereas the character of Zubaydah represents 
myth, those of Zahrah and her elder brother, Ya-Shareef, represent the ethics of Nego-feminism. The characters are presented in a thorough discussion that is balanced and acceptable for life expectation between husband and wife. Gimba subtly guides his characters and the wider readership to choose Nego-feminist ethics to overcome marital challenges. Gimba's novel is a social contemporary commentary on the role of complementarity between the sexes as they discuss issues like the overbearing issue of early marriages:

The moral health of the society at large (Ya-Shareef argues), is more important than the physical health of a few members of that society ... and opponents of early marriages often conveniently ignore this . . He did admit that early marriages itself was not a panacea for the rising trend of promiscuity, but would surely decelerate its geometrical growth. And as, he believed the disintegration of the society to this growth, early marriage would most probably put a break on this crumbling process ... It was true, he also conceded, that some married women enjoyed the fancy of freelancers, but these had not become a horde as spinsters had. (54)

Gimba uses Ya-Shareef on Zahrah in Sacred Apples to accept and reject at the same time the challenge of early marriages; it is the technique of doing and undoing at the same time, which is called the doubling technique. The attention of his nearradical feminist sister, Zahrah, is drawn to the physical harm in early marriages. Ya-Shareef accepts the challenge of early marriage, and in doing so, he quickly juxtaposes that with the relevance of the moral health of their society. How do you compare the moral health of the practice with the physical health of a few members of that society? Which one does more harm? Opponents of early marriage, YaShareef adds, often conveniently ignore this. The moral health of society outweighs the physical health of a few individuals.

Secondly, he did admit that early marriage itself is no solution for the rising trend of sexual rascality, but has it not genuinely demonstrated a capacity to decelerate its geometrical escalation? As the disintegration of society is strongly linked to this escalating growth, is it not an apparent possibility that early marriage would probably put a break to this dangerous evil? The sister was silenced. As a radical feminist, one expects a reaction somehow from her since being adamant has its criminal value: it serves as a specimen of the uncivilized manners of most of the elite in spite of their education. But in spite of this, she chose to be wiser. She kept her quiet; she was smitten.

Thirdly, in his doubling technique, Ya-Shareef observes that it may not truly be contested that some married women can, by this license, choose to exercise "the fancy of freelancers," but even with this leftist opportunity, he stresses that "these had not become a horde as spinsters have" in societies across the globe (54). And 
we quickly compare this sordid observation such as that of Överlien who sees an alarming number of these young daughters, the teens, and rhetorically whether they should be called innocent girls or active young women who hit the bars and clubs and get laid at will, refusing to listen to reason from anyone since essentially it is their world, their lives and not anyone else's (345-67).

Also consider how Gimba handles the question of a woman's surname (73-4) since a woman is naturally prone to divorce by, or death of, the husband. Quite convincingly, Gimba explains, a woman taking her husband's name as her surname translates to "[a] small step in marital compromise, but a great leap towards marital subservience...." Therefore, in "[c]all them by their father's name. . .", Gimba refers to a Qur'ānic verse (The Qur'ān, 3.5). The reason is that if a name denotes identity, or ownership, it were better ... to be identified as being owned by our fathers than by our husbands (74). Gimba concludes this brand of feminism on the questionable superiority of men over women using the Last Testament, the Qur'ān, to mankind where it states that women are equal to men-no more, no less-and that, quite clearly, Gimba amplifies that “'men are a degree above women' . . . a degree of responsibility, not of superiority' (305, italics in the original).

A woman's house in paradise is tied to her obedience to her husband in the world; Ya-Shareef sees this as one of the mythopoeic tales populated in the north of present Nigeria craftily woven around the religion of Islam. He logically questions the consequences for those women without husbands: what about their fate? He asserts that it is only one of those cultural constructs, "a social preservative ... than a religious witticism" (Gimba 43). Agreeing, Zahrah adds that the myth furthers the exploitation of women in marriage. But Ya-Shareef still disagrees, arguing that Zahra's addition is suggestive of an extreme position in feminism. Rather, he chooses to sees it as a step towards ensuring obedience to husbands and commitment to the business of partnership and marriage, which is simply overdone.

Also in deflating the spirit of arrant feminism, Gimba speaks through Ya-Shareef again on a husband's right to divorce. Women are at such serious pains that at the slightest provocation, men check wives out of their houses. He explains that it is just that men exercise their right to divorce too soon. They are reckless in the exercise of this right that Allah permits at pains. "Isn't it true that of all the permissible things, Allah hates divorce most?" Zahra asks, referring to a Prophetic Hadith (154).

Similarly, when the toll of divorce fell on Zahra, she was asked to release her children to her husband because children naturally belong to their fathers (Gimba 48). Again, Gimba uses Ya-Shareef to clear this misconception. No particular parent has the sole ownership of children, and after all, the mother has the prerogative of 
ownership before the father. In Islam, Ya-Shareef explains, the father only has a chance after a couple of other female relations from the mother's side. Custody of the child under the Shari'a is given first to the mother. It is rightly believed that between a child's father and mother, the mother is closer to it because the tender and safe hands of the mother after her were the playing center of it. Those that can have custody of the child after her in hierarchical order are the grandmother, the great-grandmother, maternal aunt, aunt of the mother, paternal grandmother, father, the child's sister, paternal aunt, the child's niece, and "waliy" (a competent hand after non-availability of the fore-mentioned) (Legal Literacy Series 6).

On polygyny, consider how Gimba uncovers the fact that although one of the mysteries of life is how any polygynous and even monogamous man feeds his family, it is still not license to turn a conditional privilege (polygyny) into an indulgence. What Islam permits is polygyny on the condition that "if ye fear that ye shall not be able to deal justly with them-women; then marry one . . . that will be more suitable, to prevent you from doing injustice ..." (The Qur'ān, 3.2).

And on incessant misunderstanding in polygynous families, Gimba posits how peace can be bought and brought to all polygynous homes based on "justice." There is a huge misunderstanding in Yazid's home and Zahra intervenes, intelligently asking the women not to allow themselves to be played around with by men. In a balanced argument, she asks the women to compare themselves to a federation of states. While the states are certainly equal in the eyes of the husband who is the federal government, demonstrating all the characteristics of the big brother who holds the units together, the states have nothing to contend with each other as long as the big brother plays by the rules of the federated states (176). Converting this to a larger implication, Gimba argues that polygynous family is only a miniature community for the larger society, which is hardly disputable. The whole thing, therefore, revolves around "justice": justice in homes, justice in offices, justice in markets, shops, law courts, justice everywhere. Lili Ann Pintea-Reed says "Justice Is What Matters." If "justice" is not mysterious and therefore, practicable in places, why can the world not allow 'justice' in homes?

Still following the intelligence of Nego-feminism in Sacred Apples, we examine the incident of the furious Songhaian Labor Solidarity and the Songhaian National University students, who, together in protesting against the government for high rent for workers (8-9), stopped short of lynching a supposed government target, Zahra, who is clearly found inside her husband's government car, a cheap target. The framework of this paper, Nego-feminism, seeks reward in sexual co-existence without (or with reduced) tension. Conscious acts towards the politics of desirable social change are encouraged for sanity to return to the sexist world. It encourages the world to welcome novels and criticisms that explore any of the techniques of 
Nego-feminism in greater depth and explore the culture of gender politics on a much deeper and, perhaps, more scientific level. This is already gradually evident in new novels from Nigeria. Readers of some of these novels are expected to perform better in managing their homes, classes, and discussions anywhere using the motifs of Nego-feminism. In its uncommon sense, despite women's plight that have been multiple times in jeopardy leading to multiple consciousness, women selling Negofeminism still disallow themselves from taking 'extreme' positions in remedying the damages done to them with a view to teaching the world to learn from their lived experiences vis-à-vis the errors of womenfolk. A technical 'forgiveness' is its watchword in reconciliation skill. By implication, it is possible to tolerate ourselves in a/an (inter)national outing. Furthermore, James Baldwin's The Fire Next Time can be appropriated here to mean Nego-feminism which needs to be upstaged, since this reconciliation effort is not peculiar to Africa only. In her deliberate bold claim, Osammor adds to the possibility of Nego-feminist practice in new novels.

Osammor in her Water Lily gracefully relieves her of a spokesperson's narrative authority, in favour of the author for the new female voice: "These things happen all the time, not only in Africa but also in other supposedly civilised societies. Marriages get arranged and annulled by families for political and socio-economic reasons and not only for love. Concubines are also arranged to produce heirs if the woman taken in wedlock is unable to beget any" (11).

This alternative paradigm provides healthier relationships in order to understand conventional and heterosexual male-female relationships. Therefore, the paradigm of Nego-feminism is utterly and completely unopposed to multiculturalfeminism:by implication, it is not completely unopposed to other models which are not without their own advantages too; it is not sectional, parochial, racist. It meets the aspirations of true feminism which the (fe)male world yearns for-peaceful co-existence.

Osammor's Water Lily discusses topical issues in Nigerian marriages: grief and love, pride and humility, pain and joy, all surrounding childlessness. Given this childlessness, there is a complete lack of justice in the homes of the characters Water Lily. Water Lily's characters are four in number and paired: Nkem and Odili, Effua and Norman. The narrator tells a passionate story of suffering and great distress in childlessness, but love and life triumph over these in the end. The novel attests to the nobility, elegance and profound goodness of Nkem, the central female character, as it courageously tells a story of romance filled with excitement and novelty that override moments of shock in childlessness. The world has learnt by Eyisi et al.s efforts that it is always one among one million Nigerians that would not take a second wife if the first wife fails to bear him a child, and importantly, 
a male child (363). This is practically demonstrated in the case of Nkem, whose stepmother would not rest until her son bore her a grandchild.

The Nego-feminist angst in the drummed up injustice against Nkem is that after plenty of thought, Nkem willingly vacates her home for a second wife, not on divorce principle but out of self-will to allow a co-wife to occupy her place in her husband's home in order to, curiously, maintain the love she has for her husband. She agrees to become a mistress instead, while the second wife takes the position of a full-fledged housewife. She moves out to shield her marriage from what she foresaw: the spite of 'friends as foes', malice of 'in-laws as out-laws', and other people's outright spite for her inability to be impregnated by her husband. Is there anything that can beat this solution: "Now that I have created a vacancy in Odili's home, by moving out, people like his stepmother will now leave us in peace" (17)? But if Nkem has the surprising temerity to endure human injustices against women, nature seems to rub salt in the wounds, because as soon as the marriage between her husband and the new wife, Comfort, is consummated, the new wife becomes pregnant with Odili's baby. The pregnancy is expectedly a crushing pain to Nkem, as she could not avoid being full of spite towards Comfort. Again, how can this hate be contained in a Nego-feminist way?

Hard and hopeless as her fate is, the opportunity to undertake a visit to Britain by both of them happily reunites them. Consequently, she christens her psychological crises as "Endured-Patience" because her marriage is now blessed with a child at long last. Happily, she does not even believe heaven will be any happier than her moment of bliss; she is fulfilled and the naming ceremony is grandiose. For her, therefore, there is a 'happy ending, a characteristic of Nego-feminism.

In her essay, "The Identity of Self," Chukwuma settles for the polarities of feminism as similar enough to justify freeing the woman as a core-programme, but this paper believes that Nego-feminism always expects more to be done to a woman's "rejection of inferiority" and "striving for recognition" (ix). In deconstructing "striving for recognition," postfeminist discourse in new novels, particularly Water Lily, finds it hugely contrary to the spirit of upstaging womanhood to the true state of her being. Chukwuma's phrase, "striving for recognition," is a frowned-upon one, like Magaga Alot frowns upon those who, unknowingly, approach Negritude as a "defeatist and apologetic black attitude" (Alot 69). It implies, for example, one explaining to the world, "But we blacks are also people. We are also good. We also have a culture. In fact, we have a very sweet culture, we are very sweet people. .." (69). This "striving for recognition" is misleading. It is like an unarmed man, "who, accosted by 'panga gangsters' and pressed down to have his head chopped off his neck, cries out, invoking Christian virtues: 'Thou shalt not kill, thou shalt not kill...' To such a person we'd surely say: 'Thou shalt be killed anyway' " (69). 
Postfeminist discourse in new novels is simply devoid of such acclaims. It does not force out recognition from the male class, yet it achieves respect for womanhood; it does not celebrate freedom for the woman, yet it guarantees the truest mutuality for the sexes.

Water Lily holds out a more confident hope of feminist regeneration than postulated in, for example, the highly celebrated Efuru and The Joys of Motherhood (two popular feminist novels in Nigeria) because Water Lily has shifted ground from excessive antagonism to a gentle version of masculinity contingent on the forging of new identities. The male characters of Nego-feminist novels are, 'by nature' or because of their socialization, not sexual predators and therefore, usually not deeply immoral as in radical feminist texts. Male characters who depart from this pattern are rarely found-and those who do are powerless in these novels. This powerlessness is symbolized either by their premature death or by their inability to realize their positive ambitions which would have left the female characters devastated as they are being physically battered, sexually assaulted, and emotionally abused in their inescapable state of vulnerability, thereby reducing them to sexual assault survivors.

A further fundamental characteristic of these texts is their distance from tragedy and violence. The female characters do not suffer physical and psychological violence at the hands of men and vice versa. At least, a partial improvement in the situation of men and women is acceptable. In contradistinction, the radical texts are distinguished by a disturbing lack of perspectives. Thus, for example, death and murder carry the end of most radical texts. The radicalist approach is often tied to the fact that their female characters are also oppressed on the basis of, for example, their socio-economic status and/or racial identity. Thus, the gender question is often combined with an examination of other matrices of subjugation. Men, however, are not even depicted as allies in the struggle against these forms of subjugation. These texts display a devastating pessimism, fundamentally denying any hope of a transformation of prevailing gender relations. Not even the reproduction of patriarchal structures through women's behavior is described as surmountable. At the most, sisterhood or solidarity among women is shown only as a possible source of comfort or a blurred anchor of optimism.

Water Lily is pioneer third-generation women's literature in Nigeria. Osammor's novel is recorded in the story of the mutual co-existence of the sexes. Her novel is, then, representative of Nego-feminist literature. It exercises a partial criticism of patriarchal gender relations, primarily gender inequality, and also describes these circumstances as reformable, transformable. Accordingly, Water Lily assumes men's willingness to (partially) rethink. 
Nego-feminism is at its best when narrating the complicated train of trial and tribulation on Nkem's assumed barrenness. In its positive applicability to the world, it claims that a woman is worked to the bones, and yet she is thoroughly committed to disallowing herself from taking an erroneous, extremist position in remedying the damage done to her; the author writes with a particular view of teaching the world to learn from Nkem's experiences. The world is invited to respect 'mutuality between the sexes.' In what appears to be surrendering to the pressures from the outside world on her peace at home, Nkem knows that it is just a question of time before the pressures start having a negative effect on their relationship; she is thoughtful and calculative. It is not likely that women with a deep sense of feminism today will consent to vacating their home for another woman. For the first time, perhaps, Osammor, through Nkem, has helped the world to see how possible it is to be accommodative through "how possible it is for a woman to love a man totally; just for himself and not for the fact that he was the father of her offsprings or the provider of her personal comforts" (86).

This bold claim is the new position, new voice, the fire this time in 21st century literature. Peculiarly, the arranged marriage is not coming from the family but from the first wife herself. She has decided to become the woman outside, an outsider within, like Janice D. Yoder and Patricia Aniakudo's article, "Outsider within the Firehouse: Subordination and Difference in the Social Interactions of African American Women Firefighters." Nkem's resolve to move out of her legitimate house is the very underlying factor for anti-masculinity and anti-femininity. In this new feminism, while male chauvinism vanishes, it is not replaced by a role reversal, or by feminist ego. It is the coming together of men and women for harmonious survival where there is no victor nor vanquished. Thus, despite the peace that turns to pieces as the woman of the house, the failed woman (because she failed to provide her husband with a baby), Nkem still surprisingly decides to hang on to her husband, Odili, and does this in a queer way. Nkem, the supposed counselee (because she is psychologically troubled and she is now separated from her wicked step-mother) turns to counsel the counsellor, Efua. She is worth quoting, discussing the issue with her best friend, Efua: "Don't look so crestfallen, Efua. It is not like you think. I now stay at Apapa but Odili is still very much part of my life. He is welcome to come and see me whenever he pleases; as a matter of fact, the house where I'm staying belongs to him. He insisted that I moved into his property" (Osammor 9-10). And this peculiar "mentor-mentee" system sounds "crazier and crazier by the minute" (Osammor 10) to Efua, the supposed counsellor. In a quite arresting conclusion, Nkem submits that,

I had to move out of Odili's house, so as to preserve and keep as strong as I could, the love that we share. I know it sounds paradoxical or ironic, that I have to keep away from the person, so as to be able to continue loving him the way I do love Odili; but you 
see, the circumstances in which we've found ourselves are unusual and so we've had to device ingenious steps to remedy the situation. (Osammor 17)

\section{HOW MANY FEMINISTS CAN DO THIS?}

Another Nego-feminist characteristic in this text is also manifest in the liberal portrayal of men. Odili, who at first refuses to agree with the idea of Nkem moving out to another house because it is preposterous, after a while began to appreciate why Nkem did it at all. She moved out to shield their marriage from what she saw coming. To live under the same roof with a woman that one cannot protect from the malice of one's husband's stepmother, etc. is to push the woman forcefully into total disgrace and untold psychological turmoil. The relationship would then be unimaginably threatened. This liberal portrayal goes along to recommend that men should come as low as to accept their women's proposition. This is why Odili insisted that Nkem should relocate to one of his three properties instead. This liberal portrayal goes along with the fact that gender relationships in family life are not questioned. For example, pains are taken to emphasize that at no time does the woman, in this case, Nkem, neglect her duties as wife. "I sincerely love him Efua," she says in a pensive voice; "he means so much to me," she adds, so that in spite of the seeming injustice of accommodating a second wife, she succumbs to the need for the second wife (Osammor 17). Her husband does not need to curb himself in his desire for a baby, nor does he have to assume impotence as well because he loves his wife. In contrast, a man with a wife is not expected to show lack of concern/need for children on the one hand, and lack of consideration for his wife on the other. The husband, for example, spends his life between the two demands; the demands of his stepmother and that of his loving wife, while his wife is busy trying to protect her marriage that is built on sound love; his attitude is not criticized. Rather, the situation is rewarded: "I have also decided to embrace the idea of becoming Odili's 'Mistress' and believe me, I am beginning to enjoy it - what with the independence and peace of mind that go with it" (17).

Thus, the myth that men are the head of the family and that women must forego their own wishes in the interests of their husbands is only to a certain extent revitalized here. Osammor is not interested in a redefinition of existing conceptions of (wo)manhood and an overcoming of the traditional roles of husbands and wives. What is demanded are new options and scope for spouses within existing social frameworks. A good illustration of this approach is the novel's position, where Nego-feminist demand is claimed. Here measures are demanded that will make it easier for women to take control of their lives, without, however, calling the principle of existing gender relations into question. Thus, for example, recourse to God to take control is urged. Nkem has by this singular drama become a strong 
believer in the Lord; she has become a church goer and choir member (Osammor 19).

Ultimately, Stella Osammor is concerned not with the fundamental transformation of gender relations, but with a partial alleviation of the burdens of the female sex, a partial improvement which is also a serious contribution to lifting the fog on womanhood; a partial improvement of the situation of women since no one method may efface all crises. Women can observe their traditional responsibilities, but should also be given new rights and possibilities.

The main focus of Water Lily is polygyny. The story, which exploits men's decision to take second wives, shows not only men, but women too are culpable for the gender relationships discriminating against women. The author shows that women make life hard for fellow women, and how they do this. For example, older women use the power offered to them by social hierarchies to satisfy their interests unconditionally, not caring that they may be destroying the lives of their daughters, daughters-in-law, and other young women in the process.

But alongside this woman-on-woman discrimination, women's part in their own subjugation is addressed positively. Even in the radical feminist Mariam Bâ's So Long a Letter, for example, she hints at the possibility of Nego-feminism where Ramatoulaye finishes her letter saying, "I warn you already, I have not given up wanting to refashion my life ... The word 'happiness' does indeed have meaning, doesn't it? I shall go out in search of it" (89). Implicitly in the process of writing her letter and reflecting upon her life, Ramatoulaye starts to rethink and to change. She has already become dynamic in her thinking and behavior. This dramatizes the possibility that women's reproduction of traditional gender relations-their participation in their own 'victimization' as well as the 'woman-on-woman' discrimination-can be overcome. But it is incumbent upon women novelists to take the initiative such as Osammor is doing. Other novelists need to emulate her.

By taking up the idea of complementarity and closely interrelating it to love, Osammor does not only have the family context in mind, but hints at the wider implications of the way a married couple organizes their life. Every nation of the world is made up of families. The success of a nation therefore depends inevitably on the family nucleus. Thus, just as true love, Nego-feminism promises health of complementarity, as it in turn guarantees harmony in partnership. Happy families are the stepping stone toward a harmonious society.

Osammor's Water Lily, therefore, starts and ends with a turnaround that essentially regenerates a woman's pessimism. To appreciate how much this is a statement of faith and a refusal of despair, we have to keep step with Osammor as 
she traverses Nigeria's sum of postfeminist literary discourse. It would be wrong of Alot to conclude, therefore, that followers of Martin Luther King Jr. who put their faith in the "power of love" to win hearts are simply "lunatic" (69). He would make sense if he had recognized the fact of a possibility of winning substantial hearts, as no one would lose the foresight not to acknowledge the fact of exceptions in all general laws. Those who live by the margins, therefore, would be inconsequential. This simply is what Nego-feminism harbors its faith on as exemplified in Efua and Nkem (the two lead female characters). Nego-feminism has the capacity to radiate love and in consequence, win significant hearts. The world cannot continue to be careless in its conceptions of gender injustice. Someday, and that day is in fact here, we would live to see a change in the order of the world. The world will experience substantially greater justice in terms of gender relations.

Following the above, a husband is not to hate his wife. If he dislikes something in her character, he should be pleased with some other traits of hers and vice versa. This is a commodity for lasting peace between couples, regardless of one's religion as it has no peculiarity to one culture or religion. Marriage specialists advise that one should be as specific as being compassionate, cheerful, devout, faithful, committed, confident, optimistic, gentle, affectionate, honest, confident, elegant, creative, kind, and generous. Other aspects of bedroom politics in John Gray's Mars and Venus in the Bedroom add to the endless list.

In selling characteristics of Nego-feminism in texts, both century-old and modern individual patriarchally molded attitudes, norms and conventions, which discriminate against the female sex and hamper their self-realization, are definitely reproached but the knock is only partial, and is usually brought forward in a differentiated way. Nego-feminist novels prefer to negotiate understandable shares with the patriarchal order. Importantly, alternatives to what is reproached are always discussed in these novels. It is assumed that the society is capable of change, and therefore, there is usually a 'happy end.' Moreover, a tolerable treatment of men is very characteristic of these novels: men are criticized as individuals, not as representatives of men as such. Men's criticism is always handled with a very generous slant: they are usually given agreeable sides as they have the power to rethink and overcome their shortcomings, though only partially and within the obvious confines offered by patriarchal order. Therefore we often find, in these novels, female characters also bearing responsibility for the criticized aspects. Women also are women's problems. They, to a large extent, aid and abet other women's subjugation even though this connivance of women has a habit of playing a subordinate role. In these cases, it is usually indicated that women and men are partners when it comes to taking a stand against these exploits. 
Contrary to literary materials that are not of a Nego-feminist persuasion, such texts and criticisms demonstrate essential and fundamental critique of patriarchal social structures. Most sharply, discriminatory behavior by men is described as typical for men as a social group. In this way, men are identically hopelessly sexist and usually deeply immoral. Also generally speaking, the fact that women-as a consequence of their socialization-reproduce those very gender relationships which discriminate against women is thematized. It is in this light that Patricia McFadden, in her unwavering attack on African patriarchy, Western capitalism, and neo-colonialist interventions lists the attributes to include

persistence of notions of male conjugal rights; refusals to recognize marital rape as a crime; allowance of polygamy and rampant sexual mobility; notions of paternity which define children as the property of the man rather than emphasizing the responsibilities and obligations of parenting in democratic family relationships; inheritance practices that allow men to inherit women as a form of property/as slaves of male controlled families. (4)

Conversely, characteristics of Nego-feminist novels describe ways of life which represent positive counter-concepts to what is criticized in the radical stretch. Such alternatives are also realizable independently of the man who turns over a new leaf. If these alternative ways of life are not opened up to the protagonist, they are at least accessible to (wo)men readership on the whole. Within this group, texts which thematize the gender question alone as well as texts which additionally illuminate one or several other mechanisms of oppression can be found but not exploited to advantageous radical stretch. Above all, these texts imply that men and patriarchal women are (at least potential) allies in the fight against these forms of discrimination.

Therefore, the need for such alternative revision and other possible types in both men and women writers, critics, and teachers of literature is important and should not be overlooked, cannot be overlooked. Indeed, we should reassess the potency of Molara Ogundipe-Leslie's caution, "there is no such thing as 'the African woman." Ogundipe-Leslie adds that this is so because "[s]he cannot be essentialised in that way; rather she has to be considered, analysed and studied in the complexity of her existential reality. .." (9). If "there is no such thing as 'the African woman,' " this will totally agree to serve as undercover for what this paper forwards for global practice, for, if specificity may not be peculiar to 'the African woman', do we guess correctly when we infer that back in 1970, Felman's position was exactly along this thinking? Freedman quotes Felman's angle of feminism as a "real otherness ... (which) is uncanny in that it is not the opposite of masculinity but that which subverts the very opposition of masculinity and femininity" (cited in Freedman 98). Gallop adds, "This problem of dealing with difference without constituting an opposition may 
just be what feminism is all about" (93). It is neither seriously different from Jan Jindy Pettman's Worlding Women based on international relations analysis. Nor is it different from Oyeronke Oyewumi when she makes case for "a global 'sisterhood' " following African's pattern of "profound sisterly relations (that) are to be found in co-mothering ... not reducible to biological motherhood" (13). This is what Henry Louis Gates also signifies in The Signifying Monkey. It is not impossible to signify unity of purpose. Thus, these significations agree completely with the chosen strategy now named as Nego-feminism and explored in this investigation. This call for the interrogation of Nego-feminism, it can be argued, has now been heeded to by men and women writers on African women's writing in other new novels, such as has partly been demonstrated in Sacred Apples and Water Lily, although no one novel may exhibit all characteristics of a culture.

With wide-ranging curiosity and insight unhampered by assumptions or ideology, this feminism shows how men and women should couple up-turning the big picture upside down. Nego-feminism locates the argument in time and place, to find new men, new women and new narratives that prove it. In some of the new novels in Nigeria, we can see how, regardless of gender, we can adapt to the new reality and channel our grievances. With this feminism, it peculiarly reveals how both the new Nigerian, African and global woman's state of affairs can shift the dynamics between men and women at every level of society with profound implications for marriage, sex, children, work, and more. In this Negofeminism, its novels are particularly effective in getting men and women as active forgivers. In this way, Nego-feminism is part of a larger process of re-imagining gender for unlimited possibilities. Within the spirit of the new feminist disposition, oppositional feminism (i.e. anti-masculinity and anti-femininity) should unfold locally and nationally with the componential gender activisms transforming into transformed peace groups, exploiting in their places the techniques where processes of dispute resolution for disagreeing parties agree to resolve their crises without litigation, an enviable Nego-feminist spirit.

The death of sex is, then, in sight when we consciously form group dynamics to implement the matrices of Nego-feminism. Basically, after reading Nego-feminist novels, one should feel (completely) transformed and hate to be reminded of the 'radical' past because that was the feminist then, and this is the feminist now. In fact, one develops hatred for tragic novels, films, poems, etc.; one distances oneself from crime novels, horror films, etc. Becoming a Nego-feminist is a welcome distraction from previous man-hating and woman-as-beast stances. Nego-feminism is now somehow squaring the circle by diffusing the tension between feminists. And it is important to ask, are Nego-feminist characteristics breathing soul into the lives of people by inviting them to a higher calling, helping to reclaim the watchwords of feminism? Does the conversion to alternative Nego-feminism among men and 
women augur healthily for feminists' future? For anyone who has taken in with Nego-feminism, the answer to these questions is a resolute yes.

\section{CONCLUDING THOUGHTS: FEMINISTS PRESENTING A NEW PRESENT AND FUTURE}

In a lecture titled "Women and Creativity" delivered at the University of Illinois at Urbana-Champaign on March 12, 1998, Nawal el Saadawi argued for the universality of creativity,

All of us, whether we are men or women, whether we are poor or rich, young people from the peasant class or from the upper class, whether the governing class or the governed, we are all creative, but then what happens to us is that many obstacles interfere with our creativity. So, we are creative by nature, just because we are human beings.

Indeed, creativity is a universal gift; it is not peculiar to tribe, culture, or race. A good idea can shoot from anywhere, just like Nego-feminism shoots from Nigeria, Africa. El Saadawi can, therefore, be appropriated to argue for the world to benefit from Africa's creativity, Nego-feminism, if womanhood is to be taken to greater heights. For more than a decade into the 21st century, the temporal turn in studies among critical perspectives and period specialties exploring various historical, social, corporeal, mechanical, and phenomenological "time binds" is by now flourishing in such fertile countries that it has led to a number of distinct, if intertwined, branches of postfeminism like body/affect, queer studies, material and print culture, transnationalism, aesthetics, and Nego-feminism.

But, is this sameness of viewpoint of el Saadawi any different from Awa Thiam's in Speak Out, Black Sisters? Thiam argues that patriarchal order is clearly enshrined in polygyny (marrying more than one wife), sewing up the vagina (infibulation), and clitoridectomy as the weapons used by men to subjugate their women. In this book, Thiam, a black African feminist like el Saadawi, advances what most oppressed women in the world say about themselves. She argues that what any woman or group of women accept as their fate is not peculiar to them only; neither should these practices be considered "barbaric" and remote, but part of a pattern of universal injustice on women. The remedy, as revealed by this investigation, lies in action linked to Nego-feminism. This is the reason why the pioneer novels examined here indicate the emergence of what el Saadawi and Thiam propose, which is this paper's expectation of the present, the theory of Nego-feminism. Each of the two exemplary novels analyzed addresses the formations, reformations, and assurances of the present and the promising future - not just in the simple or 
superficial sense, but the ideation, theorizing, applying, and abridging the feminist present and its relations to what did not, has not, might not, or has yet to come to be, but will be. By beginning to take the present earnestly between husbands and wives, a theoretical inquiry and critical application has been injected into couples' lives.

In Nego-feminism, the whole silver lining behind a circumference of oppressing or antagonizing a bedroom mate is the fact that there is an opportunity to make a change by burying the ego and begging for forgiveness from each other. This forgiveness is letting go of the need for revenge, any sense of bitterness or resentment and to let go of the past in order to move forward together. Forgiveness is one of the gems that build a strong relationship between people. Thus, we need to confront Rodney King's very simple and very poignant question: "Can we all get along?"

To conclude, the paper's bigger implication of what the new woman is, why it is important, and how it is interpretable in the third generation of novels in Nigeria using Nego-feminism framework stresses that teachers, novelists, and feminists need to help the world to develop this new woman agenda or Negofeminist awareness. In its multiplier effect, it identifies the factors which enhance Nego-feminist agenda development. In consequence, it holds that past feminist contributions have been three steps forward and two steps back, and therefore, in Nego-feminism's gendered metaphors, it, among others, untraps masculinity, steps up to unarm the sex tourist, for example, whose ego is daughtering in visiting new places, littering the world with fatherless babies; it goes further to eschew blame transfer between the sexes; it rests with harmony between the sexes. What Hidemi Suganami fully meant in 1990 with her "Bringing Order to the Causes of War Debate" collides with Camille Sutton-Brown's “Using Millie Thayer's Making Transnational Feminism to Connect Transnational Feminist Theories to Transnational Feminist Practices"-both appear to be fully matured in the twenty-first century necessarily defined by harmony between the sexes; how they are able to keep under control the building fires of conflict in the home. A new dawn beckons: mutuality of existence between the sexes, Negotiation-feminism (Nego-feminism). 


\section{Works Cited}

Abodunrin, Femi. Black African Literature in English 1991-20o1: Critical Appreciation and Reception. Tanzania: Mkuki Na Nyota, 2006. Print.

Achebe, Chinua. "The Role of the Writer in a New Nation 1964." African Writers on African Writing. Ed. G.D. Killam. London: Heinemann, 1973. 7-13. Print.

Adichie, Chimamanda Ngozi. Purple Hibiscus. London: Fourth Estate, 2004. Print.

-.. Half of a Yellow Sun. London: Fourth Estate, 2006. Print.

Adriaens, Fien and Sofie van Bauwel. "Sex and the City: A Postfeminist Point of View? Or How Popular Culture Functions as a Channel for Feminist Discourse" The Journal of Popular Culture 47.1 (2014): 174-95. Print.

Akosu, Tyohdzuahb. "Sustaining Creative Writing in Northern Nigeria." Ed. Abdullahi Ismaila, Ismail Garba, and Kamar Hamza. Towards Sustaining Creative Writing in Northern Nigeria. Ibadan: Kraft, 2009. 33-42. Print.

Akpuda, Austine Amanze. "A Dream Beyond Pyramids: Harvest, Bazaar and Carnival in Nigerian Literature on the Post-Soyinka Nobel Prize Era." ANA Review. Lagos: Assn. of Nigerian Authors, 2010. Print.

Alkali, Muhammad. "Thematic Shiftings in the African Novel: Another Assessment." Lapai Journal of Humanities 2.1 (2008): 11-21. Print.

Alkali, Muhammad, Rosli Talif, Wan Roselezam Wan Yahya, Jariah Mohd Jan. "Liminality Space In-Between: A Feminist Evaluation of Primordial and Modern Polarities of the Woman's Journey in the Nigerian Novel." 3 L: The Southeast Asian Journal of English Language Studies 20.1 (2013): 129-42. Print.

Alot, Magaga. "Negritude, Black Aesthetics - The Myths and Realities of the Black Fact." Black Aesthetics: Papers from a Colloquium Held at the University of Nairobi, Kenya, June 1971. Ed. Andrew Gurr and Pio Zirimu. Nairobi: East African Literary Bureau, 1971. Print.

Arndt, Susan. "Perspectives on African feminism: Defining and Classifying AfricanFeminist Literatures." Agenda 17.54 (2002): 31-44. Print.

Atta, Sefi. Everything Good Will Come. Moreton-in-Marsh: Arris, 2005. Print.

Bâ, Mariam. So Long a Letter. Trans. Modupé Bodé-Thomas. Johannesburg: Heinemann, 1989. Print.

Baldwin, James. The Fire Next Time. New York: Knopf Doubleday, 1963. Print.

Bellafante, Ginia. "Feminism: It's all about me!" Time 29 June 1998: 54-62. Print.

Brunsdon, Charlotte. "The Feminist in the Kitchen." Feminism in Popular Culture. Oxford: Berg, 2006. Print.

Bryce, Jane. "Half and Half Children: Third-Generation Women Writers and the New Nigerian Novel." Research in African Literatures 39.2 (2008): 49-67. Web. 2 Jan. 2012.

Chukwuma, Helen. "The Identity of Self." Feminism in African Literature: Essays on Criticism. Enugu: New Generation, 1994. Print.

--. "Positivism and Female Crisis: The Novels of Buchi Emecheta." Nigerian Female Writers: A Critical Perspective. Ibadan: Malthouse, 1989. Print. 
Davies, Boyce Carole, and Anne Graves Adams, eds. Ngambika: Studies of Women in African Literature. Trenton, NJ: Africa World, 1986. Print.

de Berker, Paul. "Group Processes in Negotiation." Proceedings of the Royal Society of Medicine 67.9 (1974): 959-62. Print.

el Saadawi, Nawal. "Women and Creativity." University of Illinois at Urbana-Champaign. 12 Mar. 1998. Lecture.

Exner, T.M., J.E. Mantell, and L.A. Adeokun. "Mobilizing men as partners: the results of an intervention to increase dual protection among Nigerian men." Health Education Research 24.5 (2009): 846-54. Pritnt.

Eyisi, Joy, Ike Odimegwu, and Ngozi Ezenwa-Ohaeto. African Literature and Development in the Twenty First Century: Proceedings of Ezenwa-Ohaeto International Memorial Conference. Owerri: Living Flames Resources, 2009. Print.

Flavell, J.H. "Metacognition and Cognitive Monitoring: A New Area of CognitiveDevelopmental Inquiry." American Psychologist 34.10 (1979): 906-11. Print.

Freedman, Barbara. "Frame-Up: Feminism, Psychoanalysis, Theatre." Feminist Theatre and Theory. London: Macmillan Press, 1996. Print.

Gallop, Jane. The Daughter's Seduction, Feminism and Psychoanalysis. New York: Ithaca, 1982. Print.

Gimba, Abubakar. Sacred Apples. Ibadan, Nigeria: Evans, 1994. Print.

Gray, John. Mars and Venus In the Bedroom: A Guide to Lasting Romance and Passion. New York: HarperCollins, 1995. Print.

Griswold, Wendy. Bearing Witness, Readers, Writers, and the Novel in Nigeria. Princeton: Princeton UP, 200o. Print.

Kolb, Deborah and Kathleen McGinn. Beyond Gender and Negotiation to Gendered Negotiations. Cambridge, Mass: Harvard Business School, 2012. Print. 09-064.

Legal Literacy Series 6: Custody of Children under the Shari'a. Women's Aid Collective (WACOL), 2003. Print.

Loe, Meika. "The New View in Action: College Students Discuss 21st-Century Sexuality." Feminism and Psychology 18.495 (2008): 495-504. Print.

"Man Who Burnt Wife with Hot Iron Opens Up, As Emotions Pour in for Burnt Wife." Vanguard 28 Apr. 2012. Web. 28 Jan. 2014.

McFadden, Patricia. "Political Power: The Challenges of Sexuality, Patriarchy and Globalization in Africa." Women's World. Women's World, n.d. Web. 28 Jan. 2014.

McRobbie, Angela. The Aftermath of Feminism: Gender, Culture and Social Change. New York: Sage, 2008. Print.

Miller, Offir. "The Negotiation Style: A Comparative Study between the Stated and inPractice Negotiation Style." Procedia: Social and Behavioral Sciences 124.1 (2014): 200-09. Print.

Min, L.H., P.H. San, Y. Petras, and A. Mohamad. "Novice Writers in Asian Academia: Insights on Writing Issues." 3 L: The Southeast Asian Journal of English Language Studies 19.3 (2013): 47-60. Print.

Morawski, Jill. "Moving Gender, Positivism and Feminist Possibilities." Feminism and Psychology 15.4 (2005): 408-14. Print.

Morgan, Robin. Sisterhood is Global. New York: Anchor, 1984. Print. 
Nadaswaran, Shalini. "Rethinking Family Relationships in Third-Generation Nigerian Women's Fiction." Relief 5.1 (2011): 19-32. Web. 29 Jan. 2012.

Nnaemeka, Obioma. "Nego-Feminism: Theorizing, Practicing, and Pruning Africa's Way, 1999." Journal of Women in Culture and Society 29.2 (2003): 357-78. Print.

Negra, Diane. What a Girl Wants? Fantasizing the Reclamation of Self in Post-Feminism. London: Routledge, 2009. Print.

Nwajiaku, Ijeoma C. "In Search of an African Gender Ideology: Kolawole's Womanism and African Consciousness and Acholonu's Motherist Alternative." Gender Theories and Polemics: A Critical Source Book. Ed. Yetunde O.O. Akorede and A.A. Asinyanbola. Porto Novo: Sonou Press, 2010. Print.

Nwosu, Maik. “The Mapping of a Generation." Sunday Vanguard 7 May 20oo. Print.

Ogundipe-Leslie, Molara. Re-creating Ourselves: African Women and Critical Transformations. Trenton, NJ: African World, 1994. Print.

Ogunyemi, Chikwenye Okonjo. African Wo/man Palava: The Nigerian Novel by Women. Chicago: U of Chicago P, 1995. Print.

Osammor, Stella Ify. The Triumph of the Water Lily. Ibadan, Nigeria: Kraft, 1996. Print.

Oyewumi, Oyeronke. African Women and Feminism: Reflecting on the Politics of Sisterhood. Trenton, N.J: Africa World, 2003. Print.

Överlien, C. I. "Girls or active young women? Negotiating sexual agency at a detention home." Feminism \& Psychology 13.1 (2003): 345-67. SAGE Journals. Web. 10 Aug. 2012.

Pettman, Jan Jindy. Worlding Women: A Feminist International Politics. Crows Nest: Allen \& Unwin, 1996. Print.

Pintea-Reed, Lili Ann. "Justice Is What Matters." Feminista! July 1999. Web. 19 Jan. 2013.

Raven, Charlotte. "How the 'New Feminism' Went Wrong.” The Guardian 6 Mar. 2010. Web. 12 Feb. 2011.

Scott, Joan Wallach. "Feminism's History." Journal of Women's History 16.2 (2004): 10-29. Print.

Suganami, Hidemi. "Bringing Order to the Causes of War Debate." Millennium 19.1 (1990): 19-35. Print.

Sutton-Brown, Camille. "Using Millie Thayer's Making Transnational Feminism to Connect Transnational Feminist Theories to Transnational Feminist Practices." The Qualitative Report 15.3 (2010): 727-30. Web. 19 Jan. 2013.

Tasker, Yvonne and Diane Negra. Interrogating Postfeminism: Gender and Politics of Popular Culture. London: Duke, 2010. Print.

Tavris, Carol. "Revisiting Some Feminist Classics in Light of the New View." Feminism and Psychology 18.4 (2008): 557-63. SAGE Journals. Web. 17 Sept. 2012.

"The Freak Show." Sex and the City. Writ. Jenny Bicks. Dir. Allen Coulter. New York: Home Box Office, 1999. DVD.

Thiam, Awa. Speak Out, Black Sisters: Feminism and Oppression in Black Africa. London: Pluto, 1986. Print.

Yoder, Janice D. and Patricia Aniakudo. "Outsider within the Firehouse: Subordination and Difference in the Social Interactions of African American Women Firefighters." Gender and Society 3 (1997): 324-41. Print. 